\title{
DAVID ROGERS (1917-1995): A MEMOIR AND A TRIBUTE
}

\author{
by ANTONy Allison
}

$\mathrm{D}^{\prime}$ AVID ROGERS, co-founder and for many years co-editor with me of Recusant History died at his home, the Old Mill at Blewbury, Oxfordshire, on 31 May 1995. He had been in poor health for some years but, in the end, death came unexpectedly suddenly. My wife and I, with our friend Tom Birrell, visited him at Blewbury only a week before he died. We found him frail but in good spirits. It was a perfect summer afternoon and he took us (propelling himself in his electric wheel-chair) round his beautiful garden with its mill-stream, talking to us about the flowering shrubs and trees and discussing changes he was proposing to make. We little thought then that we should not see him again. A week later he died of a heart attack.

Since his death there have been several glowing obituaries of him in the national press outlining his career and listing his achievements as a scholar librarian. The present memoir will be more personal than anything that has so far appeared-much more so, indeed, than is usual in contributions to a journal of this kind. I shall simply draw upon my recollections of a friendship and a working partnership that went back many years and pay tribute, as best I can, to the qualities of mind that David brought to the work we did together. We had collaborated for so long and in such complete harmony that I had come to look upon him as a brother and it is as a brother that I mourn his death. It seems appropriate, therefore, to begin with the words with which Catullus laid funeral gifts on his brother's tomb:

Advenio has miseras, frater, ad inferias

Ut te postremo donarem munere mortis.

David and I first met in 1948 not long after we had both returned from war service overseas. He had joined the staff of the Bodleian Library and I had become an Assistant Keeper at the British Museum. We were drawn together by a common interest in early printed books and the moves then under way to revise and supplement the Bibliographical Society's Shorttitle Catalogue of English books to 1640 (STC) first published in 1926. We were both struck by the fact that STC was particularly weak in its coverage of Catholic books and pamphlets printed either secretly in England or at presses abroad working for the English Catholic market and shipped surreptitiously into the country, at a time when such literature was prohibited by law. We were fortunate in having access to the unpublished notes of two pioneers in this field, the late Dom Raymund Webster O.S.B. (who had taught David at Downside and was still living in 1948), and the late Father Charles Newdigate S.J. who had died early in the war and whose notes preserved at Farm Street were made freely available to us. We decided to compile a catalogue of such books and to investigate the problems 
concerning their authorship and the extraordinary circumstances in which they were produced. Work was slow as this was an unofficial enterprise undertaken in our own time and at our own expense. We did much of it together, especially in the big libraries, but we also went our separate ways to examine collections in innumerable small colleges and convents. I carry in my mind an unforgettable picture of David mounted on an old bicycle ('Minnie'), with his travelling gear and all his heavy notebooks strapped perilously onto it, pedalling his way, a twentieth-century John Leland, across the length and breadth of the country, assisted only by a small outboard motor that operated directly on the back tyre to the great danger of the rider especially in wet weather when roads were slippery. But he survived unscathed. In 1955 we published our findings to date in a small catalogue of just under a thousand entries: $A$ Short-title Catalogue of Catholic Books in English printed abroad or secretly in England, 1558-1640. Its contents were much later incorporated, in a greatly enlarged and revised form, in volume II (published in 1994) of the last work that David and I compiled together, The Contemporary printed Literature of the English Counter-Reformation between 1558 and 1640 (ARCR). Volume I of that work, comprising foreign material relating to the same theme, had appeared in 1989.

Our work both in England and abroad led to some happy finds. For example, we discovered that the Irish College at Paris, which survived the French Revolution and still exists today on its old site in the rue des Irlandais, preserves the remains of the library of the former English College of St. Gregory, founded in the late seventeenth century for English secular priests studying at the Sorbonne. That library inherited many books that had belonged to still earlier English foundations at Paris and some of them bear autograph inscriptions going back to the beginning of the century. It had for long been assumed that the library had perished, together with much other English material, during the Revolution, but it seems that at least part of it was deposited for safe-keeping at the Irish College where it had remained unrecognised ever since. Another interesting find was at the library (now owned by the State) of the former Strahof Monastery at Prague. There we had the good fortune to light upon what is probably the only surviving copy of the Spanish translation, printed at Saragossa in 1629, of Benet of Canfield's mystical treatise, The Rule of Perfection. The translation, which comprises all three parts of the work, was made by the poet Bartolomeo Leonardo de Argensola and dedicated by him to Margarita de la Cruz, niece of King Philip II, of the royal Carmelite convent at Madrid. But it fell foul of the Spanish Inquisition which suppressed it, and no copy was known to have survived. We had searched for it in vain throughout Europe. Another find was at Oscott College, Birmingham, where a box of unsorted manuscripts yielded two unpublished works by the seventeenth-century priest and traveller, Richard Lassels, whose career and travels in Italy form the basis of Dr. Edward Chaney's The Grand Tour and the Great Rebellion, 1985. Fortunately, this occurred in time for Chaney to consult the works 


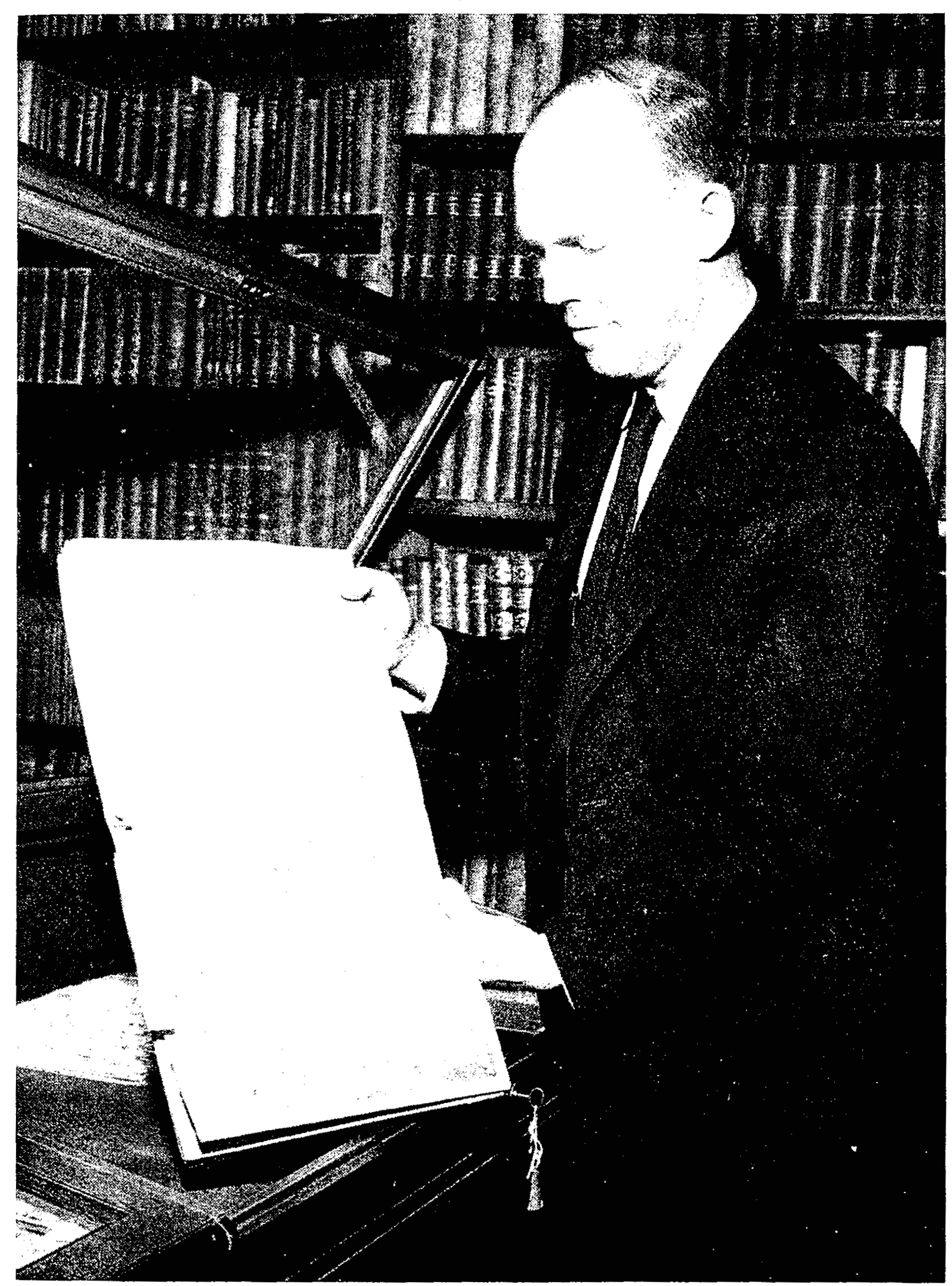

DAVID ROGERS, 1917-1995

[By courtesy of Oxford \& County Newspapers]. 
before completing the thesis that led eventually to the publication of his book. But if there were many such happy examples of serendipity, there were also, inevitably, many disappointments. Some books known from contemporary evidence to have been printed, including several that had been seen by bibliographers in comparatively recent times, seemed to have disappeared altogether; some libraries that we thought would be worth the trouble and expense of travelling a great distance to visit proved to be almost barren of the kind of material we were looking for. And there were near-calamities as well. One of the most dramatic occurred about fifteen or sixteen years ago, quite late-on in our partnership. David was coming to spend a weekend with me bringing all his notes and catalogue slips with him in his ancient and not very trustworthy car. On the way, stopping to fill up with petrol, the engine suddenly burst into flames. David managed to get out unharmed but the flames quickly spread and he was forcibly restrained from going back to rescue his precious cargo on the back seat by firemen who told him the whole car might blow up at any moment. But by good fortune or divine providence the flames died down. David's notes and catalogue slips were a little charred at the edges but otherwise intact.

In 1950 David and I, in collaboration with my father who ran a small provincial publishing firm, launched a periodical which we called Biographical Studies. The idea came to us, if I remember rightly, as the result of a conference held in London at about that time to discuss the feasibility of publishing a Catholic historical review in England. Many distinguished scholars, as well as others with a general interest in the subject, were present, among them Archbishop Beck, Dom David Knowles, Mgr. Philip Hughes, Professor A. C. F. Beales, Father Leo Hicks S.J., Mr. Douglas Woodruff. Nothing came of the project, however, mainly because of the difficulty of finding a suitable editor with the time to devote to it. The three of us decided independently to attempt something far less ambitious, a periodical in which we would publish articles aimed at correcting and supplementing Joseph Gillow's biographical dictionary of the English Catholics which was by then more than fifty years old and badly in need of revision. Our periodical, reproduced from typewriting, came out twice yearly, starting with the issue for January 1951. It was edited by David and myself and published by my father at the Arundel Press. It achieved a modest success and came in time to be recognised as a useful contribution to research in its own field. After a few years we decided to widen its scope and turn it into a vehicle for the publication of research articles on any aspect of post-Reformation Catholic history in the British Isles, not necessarily biographical. The title was changed to Recusant History, we went over to proper type-setting and a more professional format, and in 1957 my father handed over responsibility for it to the Catholic Record Society thus ensuring its future continuity. Over the years it has further enlarged its scope to such an extent that it now fulfils many of the functions envisaged by the historians and others who met in London at that abortive conference of nearly fifty years ago. 
David and I stayed on as editors until the end of 1968 when we were joined by Michael Hodgetts and later by others who eventually took over full responsibility. This work, in addition to the bibliography, brought us ever more closely together. David would spend a weekend with me every five or six weeks and we sat up working late into the night long after my wife and family had gone to bed. He became almost a member of the family. To the children he was always Uncle David. He was, in fact, particularly good with children and loved talking to them and reciting poetry to them, especially Belloc's Cautionary Tales. My eldest son, now a man in his fifties, still has vivid recollections of David reciting 'Jim' (who ran away from Nurse and was eaten by a Lion) and 'Henry King' (whose chief defect was chewing little bits of string) and 'Matilda' (who told such dreadful lies, it made one gasp and stretch one's eyes). There was a much lighter side to David, and he had a far keener sense of humour, than might be expected of a man who spent the greater part of his life in the rarefied atmosphere of academia. Even his learning held its attraction for children for he could talk to them about birds and butterflies and flowers with as much authority as to librarians about incunabula.

David's great personal qualities were obvious to all who came into contact with him. We remember him for his deep (but unostentatious) piety, his devotion to scholarship, his utter integrity, the kindness and generosity he showed to everyone, his patience with those less gifted than himself, his charity towards all men, even those of whose behaviour he disapproved. I should just like to add a few observations of my own about what I myself was in a special position to observe, the quality of mind he brought to the study of recusant history on which we worked together for so many years. David was a classical scholar-he read Greats at Oxford-and everything he wrote reveals the characteristics of a classicial education: precision, lucidity, order, logic, a sense of proportion and balance. He believed that presenting one's conclusions in a logical and coherent manner is as important as mastering the sources and amassing evidence. His own writing possesses an elegance that owes everything to these qualities and nothing to superficial ornament-it is truly simplex munditiis. To any prospective contributor to this journal I would recommend as models of method and style David's article 'An English Friar Minim in France' (vol. 10, no. 5, April 1970) or 'The Escape of Thomas Tichborne' (vol. 19, no. 4, October 1989) or, more recently, his long note (written entirely by him) on Sir Herbert Croft in vol. II of ARCR (1994). He did not publish a great deal under his own name. A certain diffidence, combined with a disinclination to commit anything to print unless he could say the final word on the matter he was investigating, acted as a deterrent. But his guiding hand is to be seen in much of the published work of those who sought his advice. It also reveals itself in the shaping of many of the articles we accepted for publication in the early numbers of this journal. Some of those articles were largely rewritten by David though they appeared under the names of other writers.

In a recently broadcast short interview for the BBC Mr. Enoch Powell recalled his memories of the great classical scholar and poet A. E. Housman 
under whom he studied at Cambridge in the early 1930s. I was much impressed by Mr. Powell's remark that Housman showed in his lectures on the classics an intensity of emotion that might not have been expected in a scholar renowned above all for rigorous textual analysis. It was that same emotion, of course, that found its full expression in Housman's own poetry. I could not help being reminded of David. He too combined a passion for pure scholarship with intensity of poetic feeling. He loved poetry, especially of a nostalgic and elegiac kind such as we find in Housman. On our long walks together we would often, as a relaxation from discussing work, amuse ourselves by trying to reconstruct from memory some of our favourite long poems, such as Gray's Elegy or Arnold's The Scholar Gypsy. He had an exceptionally retentive memory. I well remember an occasion less than a year before he died when a friend drove him over to Oxford to spend the day with Tom Birrell and myself. It was one of those occasions when one talks of anything and everything in a way that comes so naturally to old friends. For reasons now forgotten, Tom and I quoted the well-known elegy by William Cory on the poet Heraclitus of Halicarnassus, with its haunting lines, 'Still are thy pleasant voices, thy nightingales awake, for death he taketh all away but them he cannot take'. David, without hesitation, quoted the original Greek epigram of Callimachus from which they are translated. When my wife and I and Tom went to see him at Blewbury a week before he died, he was still quoting Greek poetry to us.

For Catullus lamenting his brother's death there was no consolation in his grief for he believed the separation caused by death to be final. For most of us who were David's friends our pain is tempered by a belief in immortality. Nevertheless, the anguish caused by even a temporary separation is difficult to bear. Disregarding the pagan overtones, I shall conclude with the final lines of Catullus's poem, lines expressing a grief so intense that they have continued to stir men's hearts for two thousand years:

Accipe fraterno multum manantia fletu,

Atque in perpetuum, frater, ave atque vale. 